mingel (whether by coincidence or design no one knows) then I would not urge you to buy this book. But Flann O'Brien, who spent his literary life pushing satire to its outermost limits, would undoubtedly have drawn much inspiration from its pages. And one final consideration: it was said that when Aldous Huxley was passing through his phase of reading the Encyclopaedia Britannica, so ravenous was he for knowledge, his conversation would for one excruciating month be confined to topics ranging from Brassica to Caernarvon and the next to anything from Caesar (Gaius Julius) to Cement. The Dent Dictionary could be put to the same use and so might help ensure that one's dinner guests do not linger too long over the port and cigars.

Walter Gratzer is in the MRC Muscle and Cell Motility Unit, King's College. 26-29 Drury Lane, London WC2B 5RL, UK.

\section{Wrangling in Washington}

\author{
Harvey Brooks
}

\section{The President's Scientists: Reminis- cences of a White House Science Advisor. By D. Allan Bromley. Yale Univer- sity Press: 1994. Pp. 232. \$28.50, £20.}

IN 1988 Allan Bromley was appointed to the two-hatted position of Special Assistant for Science and Technology to President George Bush and Director of the Office of Science and Technology Policy (OSTP). Most members of the presidential staff were already in place. The status and influence of the presidential science apparatus was then at an all-time low, having shrunk from a staff of 50 and an annual budget of $\$ 4$ million at the end of the Carter years to a staff of 11 and a budget of $\$ 1.5$ million under Reagan. Even when the President's Science Advisory Committee and the position of science adviser were abolished by Nixon in 1973, and the responsibilities of the Office of Science and Technology (OST) were returned to the director of the National Science Foundation (NSF), staff support available within the NSF for roles previously assigned to the OST exceeded that available to the director of OSTP in 1988. Moreover, relations between OSTP and Congress were grimmer than ever. Yet by end of the Bush administration in 1992, the OSTP staff had grown to 65 and its budget to $\$ 6.2$ million, and it had become the largest agency within the Executive Office, with excellent congressional relations and good collaboration with the Office of Management and Budget. The result? Many presidential initiatives and a programme and capability that turned out to be the foundation for most of the policies and programmes selected for rapid expansion by the incoming Clinton administration.

This book is a highly personal and candid account of how all this came about. It provides a fascinating new chapter in the rocky history of science and technology in the White House, a history that began in 1951 under President Truman. Bromley gives valuable insights into the institutions and inner workings, formal and informal, of government at the level of the White House; it should be compulsory reading for anybody wanting to really understand how science policy is made: a good deal of the material here cannot be found in the official documentary sources usually used by policy scholars. This is particularly true of the chapters on budgetary process and the interactions between Congress and the Executive. The book is full of surprisingly frank anecdotes and comments on people active in debates about science policy and especially technology policy in the upper reaches of the executive branch of the Bush administration. The picture of national policymaking that emerges is not always very flattering, replete as it is with turf battles and oversensitive egos, although negative and positive comments are fairly evenly balanced. The heroes and villains are not always the same as those identified by the contemporary press.

The inherent problem of science and technology in the policy process arises from the fact that they are crucial inputs to policy debates that are primarily nontechnical in character. At the same time, when budgetary issues are involved, it is difficult for the OSTP to avoid the appearance of representing the special interests of the scientific community that is uniquely dependent on federal financial support in competition with other political and economic constituencies, especially since the discretionary part of the federal budget has shrunk from 70 per cent of the total in 1960 to 37 per cent in 1993. Also, the credibility of the OSTP in all other aspects of the policy process depends on its reputation for impartiality and freedom from the suspicion of being beholden to any external constituency - a difficult balancing act that Bromley seems to have carried out with unusual skill.

Bromley is at his best when dealing with issues in which he was directly involved. For example, there is a brief discussion of the controversy over the Supersonic Transport Program in the early 1970 s and of early controversies about automobile emissions. While I happen to agree with Bromley's policy conclusions on these subjects, his discussion of the underlying science is oversimplified and partly wrong. Similarly, his explanation of the reasons for Truman's veto of the original NSF legislation is a serious oversimpli- fication of a much more subtle and complex controversy.

Indeed, the book often disappoints when it deals with the scientific basis of policy issues. For example, there was much (in my opinion unfair) criticism of the Bush administration before the United Nations Conference on Environment and Development in Rio de Janeiro in 1992 because of the administration's refusal to agree to specific targets and deadlines for the reduction of greenhouse-gas emissions. I believe that this position was absolutely scientifically defensible, but the justification that Bromley gives is vague and unconvincing.

Comparisons of US science policy with those of Europe and Japan also seem unduly simplistic and in some cases wrong. Support for science and technology in these countries, Bromley says, is centred on a single agency, in contrast to US pluralism. In fact, defence, space and atomic energy tend to be administered separately in virtually all major countries. $\mathrm{He}$ also states that "essentially all" research and development (R\&D) goes into this creation of "new knowledge" except in the United States, where 54 per cent funds the development of large public technological systems, mainly relating to defence, space and nuclear energy. Although there is a grain of truth here, these observations are so oversimplified as to be quite misleading.

Moreover, statistics on international comparisons are presented almost entirely in terms of ratios of total R\&D investment to gross domestic product, which virtually ignores the fact that US R\&D investment in absolute terms exceeds that of any of the five other major countries. No credit is given to the potential advantages of economies of scale in R\&D in the United States and the greater diversity and competition of ideas made possible by the sheer size of the country. No mention is made of the fact that in Germany and Japan a much higher fraction of total national R\&D (65 per cent and 83 per cent respectively) is financed by private companies with their own funds than is the case in the United States (50 per cent). This may possibly explain the outstanding economic performance of the first two countries.

Harvey Brooks is in the John F. Kennedy School of Government, 79 John F. Kennedy Street, Harvard University, Cambridge, Massachusetts 02138, USA.

The Fifth Branch: Science Advisors as Policymakers by Sheila Jasanoff has just been published in paperback by Harvard University Press (\$20.25, £13.50). "A provocative and original work...Jasanoff has pioneered the exploring of the workings of the gears and sprockets of the Fifth Branch [of government]," wrote Daniel S. Greenberg in Nature 349, 116 (1991). 